\title{
PENDAMPINGAN HAK-HAK PEREMPUAN DAN ANAK PASCA PERCERAIAN
}

\author{
Aziz Sholeh ${ }^{1}$, Dian Rachmat Gumelar ${ }^{2}$, Aah Tsamrotul Fuadah ${ }^{3}$ \\ 1UIN Sunan Gunung Djati Bandung \\ Email: azizsholeh@uinsgd.ac.id \\ 2 UIN Sunan Gunung Djati Bandung \\ Email: dianrgumelar@uinsgd.ac.id \\ ${ }^{3}$ UIN Sunan Gunung Djati Bandung \\ Email: aahtsamrotulfuadah@uinsgd.ac.id
}

\begin{abstract}
This article aims to provide knowledge and assistance as a form of protection for the rights of women and children after divorce, as well as to determine the supporting factors and obstacles to their fulfillment. The approach used is participatory action research (PAR). The way this is done is by providing counseling and legal assistance. The results showed that effectively assisted subjects were able to: (a) Identify social problems in their environment, especially those related to household; (b) Knowing the rights as wife and ex-wife and the rights of children; (c) Share the experiences they get from life; (d) Solve problems with solutions they think are strategic; (e) They know very little that they need help and empowerment. Furthermore, the service team assisted the litigation process at the Soreang Religious Court and the Sumedang Religious Court. In practice, the fulfillment of the rights of women and children after divorce is supported by various factors. As a supporting factor for the fulfillment of the rights of women and children after divorce, among others (1) the good faith of the husband, (2) the decision of the panel of judges that includes the husband's obligations to his ex-wife in the event of a divorce, and (3) the husband has income and / or assets sufficient to meet the demands of the obligation. While the causative factors that hinder the protection of women's rights after divorce, especially in the case of divorce, include: (1) the absence of clear and firm rules against husbands who do not carry out the pledge of divorce, which creates legal uncertainty, (2) decisions that cannot be executed. (3) low legal awareness and legal knowledge in the community.
\end{abstract}

Keyword: women's and children's rights after divorce, assistance, service

\begin{abstract}
ABSTRAK
Artikel ini bertujuan untuk memberikan pengetahuan dan pendampingan sebagai bentuk perlindungan hak-hak perempuan dan anak pasca perceraian, serta mengetahui faktor pendukung dan penghambat pemenuhannya. Pendekatan yang digunakan adalah participatory action research(PAR) dengan metode pelaksanaan dilakukan dengan cara mengadakan penyuluhan hukum dan pendampingan.Hasil penelitian menunjukan bahwa secara efektif membuat subyek dampingan mampu: (a) Mengidentifikasi masalah sosial di lingkungan mereka sendiri khususnya yang berkaitan dengan rumah tangga; (b) Mengetahui hak-hak sebagai istri maupun mantan istri dan hak-hak anak; (c) Berbagi pengalaman yang pernah mereka dapatkan dari kehidupan; (d) Memecahkan masalah dengan solusi-solusi yang mereka anggap strategis; (e) Sedikit mengenal bahwa diri mereka membutuhkan pendampingan dan pemberdayaan. Untuk selanjutnya penulis melaksanakan pendampingan pada proses litigasi di Pengadilan Agama Soreang dan Pengadilan Agama Sumedang.Dalam praktiknya, pemenuhan hak-hak perempuan dan anak pasca perceraian ditunjang oleh berbagai macam faktor. Sebagai faktor pendukung pemenuhan hak-hak perempuan dan anak pasca perceraian diantaranya adalah (1) Itikad baik dari suami, (2) Amar putusan majelis hakim yang mencantumkan kewajiban suami terhadap mantan istri ketika terjadi
\end{abstract}


perceraian, dan (3) Suami memiliki penghasilan dan/atau harta yang cukup untuk memenuhi tuntutan kewajiban. Sedangkan faktor penyebab yang menghambat perlindungan hak perempuan pasca perceraian khususnya dalam segi cerai talak antara lain: (1) tidak ada aturan yang tegas dan jelas terhadap suami yang tidak melaksanakan ikrar talak sehingga menimbulkan ketidakpastian hukum, (2) putusan yang tidak bisa dilaksanakan eksekusi. (3) rendahnya tingkat kesadaran hukum dan pengetahuan hukum di masyarakat.

Kata Kunci:hak-hak perempuan dan anak pasca perceraian, pendampingan, pengabdian

\section{PENDAHULUAN}

Penegakan prinsip keadilan merupakan salah satu ciri negara hukum. Keadilan adalah hak dasar manusia yang sejalan dengan prinsip persamaan di muka hukum (equality before the law). Setiap orang memiliki hak untuk memperoleh pemulihan (remedy) atas pelanggaran hak yang mereka derita, sedangkan negara memiliki kewajiban untuk memastikan pemenuhan hak-hak tersebut. Akumulasi dan hak-hak tersebut mengafirmasi bahwa keadilan telah menjadi suatu hak asasi manusia yang wajib dihormati dan dijamin pemenuhannya (Widiana, 2010).

Pada dasarnya perkawinan dilakukan untuk waktu selamanya, sampai matinya salah seorang suami istri. Sebagaimana yang disebutkan dalam Undang-undang Nomor 1 Tahun 1974 tentang Perkawinan bahwa tujuan perkawinan adalah membentuk keluarga yang bahagia dan kekal. Hal ini sesuai dengan ajaran Islam. Oleh sebab itu, undang-undang ini menganut prinsip untuk mempersukar terjadinya perceraian. Namun dalam keadaan tertentu terdapat hal-hal yang menghendaki putusnya perkawinan dalam arti bahwa bila perkawinan tetap dilanjutkan, maka kemudharatan akan terjadi. Dalam hal ini, Islam membenarkan putusnya perkawinan sebagai langkah terakhir dari usaha untuk melanjutkan rumah tangga.

Putusnya perkawinan ada dalam beberapa bentuk tergantung dari segi siapa yang berkehendak untuk putusnya perkawinan. Dalam hal ini, ada empat kemungkinan yaitu: Pertama, Putusnya perkawinan atas kehendak Allah sendiri melalui matinya salah seorang suami istri. Dengan kematian itu dengan sendirinya berakhir pula hubungan perkawinan. Kedua, Putusnya perkawinan atas kehendak si suami oleh alasan tertentu dan dinyatakan kehendaknya itu dengan ucapan tertentu. Perceraian dalam bentuk ini disebut talaq. Ketiga, Putusnya perkawinan atas kehendak si sitri karena si istri melihat sesuatu yang menghendaki putusnya perkawinan, sedangkan suami tidak berkehendak untuk itu. Kehendak untuk putusnya perkawinan disampaikan si istri dengan cara tertentu ini diterima oleh suami dan dilanjutkan dengan ucapannya untuk memutus perkawinan itu. Putusnya perkawinan dengan cara ini disebut khulu', dan Keempat, Putusnya perkawinan atas kehendak hakim sebagai pihak ketiga setelah melihat adanya sesuatu pada suami dan/atau pada istri yang menandakan tidak dapatnya hubungan perkawinan itu dilanjutkan. Putusnya perkawinan dalam bentuk ini disebut fasakh. (Syarifuddin, 2011).

Fakta menunjukkan bahwa perceraian khususnya cerai gugat tidak mudah dilakukan dengan capaian keadilan bagi perempuan. Banyak hasil putusan yang mengabulkan gugatan, sementara keadilan yang diinginkan perempuan melalui proses cerai gugat seringkali pupus bahkan berubah menjadi petaka ketika harus kehilangan hak nafkah, terpisahkan dari anakanak karena hak perwalian dan stigma negatif di masyarakat karena predikat janda yang disandangnya. Kondisi ini seringkali terjadi lantaran keputusan perceraian dalam perkara cerai gugat bukan berada pada inisiatornya tetapi berada dalam pertimbangan hakim. Otoritas hakim menjadi sangat menentukan. Perceraian dan akibat-akibatnya diputuskan berdasarkan kajian dan pertimbangan hakim terhadap kasus melalui tahapan-tahapan dalam persidangan.

Jauh dari hal diatas, peradilan agama merupakan salah satu sarana yang efektif untuk mewujudkan akses dan kontrol atas hak-hak material maupun non-material yang berkeadilan gender. Tetapi secara sosiologis pada aspek proses menjaga siklus kehidupan perempuan dan anak pasca perceraian juga menjadi ranah pengabdian perguruan tinggi dalam bingkai tridharma perguruan tinggi disamping pendidikan dan penelitian.

Program Studi Hukum Keluarga dan Program Studi Ilmu Hukum Fakultas Syariah dan Hukum UIN Sunan Gunung Djati Bandung memiliki perhatian lebih pada ranah ini. Mengingat 
Indonesia khususnya Jawa Barat sudah bisa dikatakan sebagai wilayah darurat perceraian karena melihat tingginya tingkat perceraian. Pada ranah inilah pendampingan dan perlindungan terhadap hak-hak perempuan dan anak pasca perceraian menjadi penting dengan tujuan untuk memberikan pengetahuan dan pendampingan sebagai bentuk perlindungan hak-hak perempuan dan anak pasca perceraian, serta mengetahui faktor pendukung dan penghambat pemenuhannya.

\section{METODE PENELITIAN}

Kegiatan penelitian ini menggunakan pendekatan Participatory Action Research (PAR) terfokus pada pelaksanaan perlindungan dan pendampingan hak-hak perempuan dan anak pasca perceraian di wilayah hukum PTA Jawa Barat dengan menggunakan metode penyuluhan hukum dan pendampingan masyarakat. Mengingat luasnya aspek yang hendak dicakup dan terbenturnya dengan kebutuhan dan waktu penulis untuk penyelesaian pengabdian ini, maka pembahasan akan turun menjadi rencana aksi yang akan difokuskan pada aspek litigasi melalui pendampingan bersama Lembaga Advokasi Syariah Mathlaul Anwar dan non litigasi melalui penyuluhan hukum dan pendampingan bagi masyarakat di Desa Talagasari Kabupaten Garut.

\section{HASIL DAN PEMBAHASAN Perencanaan (plan)}

Perencanaan ini dilakukan setelah memperhatikan kondisi riil pengadilan agama wilayah Jawa Barat dengan menggunakan analisis SWOT. Dalam menganalisis problematika di masyarakat dan menganalisis kekuatan, kelemahan, peluang dan ancaman yang mungkin terjadi pada perempuan dan anak pasca perceraian ini dilakukan dengan melibatkan masyarakat di Desa Talagasari Kecamatan Kadungora Kabupaten Garut. Alasan pemilihan Desa Talagasari sebagai lokasi pengabdian diantaranya adalah adanya kerjasama antara UIN Sunan Gunung Djati Bandung dengan Pemerintah Kabupaten Garut dalam rangka pelaksanaan kegiatan pengabdian kepada masyarakat, salah satunya dibuktikan dengan diselenggarakannya kegiatan Kuliah Kerja Nyata Mahasiswa (KKN) di desa tersebut. Selanjutnya Desa Talagasari telah mencanangkan diri sebagai Desa Berbasis Riset sesuai dengan visi misi Kepala Desa Talagasari. Sehingga kegiatan ini diharapkan dapat saling berkontribusi bagi masing-masing lembaga. Utamanya, sesuai dengan hasil riset pendahuluan, Kabupaten Garut menjadi salah satu kabupaten dengan grafik angka perceraian yang terus meningkat.

Angka janda muda di kabupaten Garut, Jawa Barat meroket dalam tiga tahun terakhir. Dalam catatan Pengadilan Agama Kelas 1A Garut, ada 12.291 janda baru sejak kasus itu diputus pengadilan sejak 2016 hingga akhir tahun lalu (Supriadin, 2019). Sehingga dari data awal tersebut penulis yakin memilih Desa Talagasari sebagai subyek sasaran kegiatan pengabdian dalam bentuk komunitas masyarakat desa.

Perencanaan ini meliputi strategi dan metode dalam memecahkan problematika yang dihadapi oleh para perempuan dan anak pasca perceraian.

Perencanaan dalam program pengabdian ini disusun secara partisipatif dengan melibatkan remaja dan stakeholder setelah dilakukan terlebih dahulu observasi, survey dan analisis kebutuhan sehingga kegiatan ini diharapkan sesuai dengan kebutuhan strategis para subjek sasaran. Perencanaan dilakukan dalam bentuk focus group discussion (FGD) pertama. Diskusi bersama Kepala Desa Talagasari ini diikuti pula oleh perangkat desa.

Dalam proses identifikasi masalah ini untuk menemukenali profil masyarakat Desa Talagasari seperti yang disampaikan oleh Bapak Riki Ismail Barokah, SH., MH. bahwa:

"Masyarakat Desa Talagasari dewasa ini lebih memiliki karakter yang mirip dengan karakter masyarakat perkotaan. Hal ini tidak lain karena lokasi geografis Desa Talagasari yang berada di Kecamatan Kadungora masih termasuk ke dalam wilayah Garut bagian kota. Bahkan bisa dibilang gerbang masuk ke Garut. Sehingga sangat rentan sekali dan cepat dalam menerima akulturasi budaya. Terlebih kaitannya dengan hal rumah tangga dan perceraian. Hampir setiap hari selalu ada masyarakat didampingi "na'ib" atau bahkan datang sendiri untuk meminta surat pengantar untuk ke pengadilan agama. Hal ini menunjukan rumah tangga masyarakat Desa Talagasari cenderung dalam posisi rentan mengalami perceraian. Kemudian 
dari segi pasca perceraiannya,karena kurangnya pengetahuan, para janda semakin diterlantarkan, rata-rata para janda kembali tinggal serumah dengan orang tuanya. Berikut juga dengan anak-anaknya, bahkan kebanyakan anak-anaknya sampai disekolahkan oleh kakek dan neneknya, mengingat para janda rata-rata bekerja menjadi buruh pabrik." (Barokah, 2019)

Focus Group Discussion (FGD) kedua bersama perwakilan pengurus Lembaga Advokasi Syariah Mathla'ul Anwar (LASMA). Dalam FGD ini lebih terfokus pada masyarakat yang langsung berhubungan dengan pengadilan, dalam hal ini pengadilan agama. Seperti yang disampaikan oleh advokat Bapak Zeni Hamdadin, S.Sy. bahwa:

"Klien kami rata-rata khususnya yang ditangani oleh LASMA terfokus pada sengketa ekonomi syariah, sengketa hukum keluarga dalam artian perceraian baik cerai talak maupun cerai gugat, harta gono-gini, penetapan ahli waris, dan lain sebagainya. Kemudian LASMA secara prodeo atau perkara cuma-cuma juga menerima dari berbagai wilayah di Jawa Barat. Kebanyakan yang kami terima adalah perkara cerai gugat. Hal ini, menjadi cerminan bahwa istri lebih dominan dalam mengajukan gugatan. Rata-rata alasan perceraian yang diajukan adalah karena alasan ekonomi dan penelantaran." (Hamdadin, 2019)

Melalui Focus Group Discussion masalah di Desa Talagasari dan lembaga pendamping LASMA adalah sebagai berikut:

Pertama, Secara umum masyarakat Desa Talagasari dewasa ini lebih memiliki karakter yang mirip dengan karakter masyarakat perkotaan. Hal ini tidak lain karena lokasi geografis Desa Talagasari yang berada di Kecamatan Kadungora masih termasuk ke dalam wilayah Garut bagian kota. Bahkan bisa dibilang gerbang masuk ke Garut. Sehingga sangat rentan sekali dan cepat dalam menerima akulturasi budaya. Fenomena masyarakat perkotaan demikian kiranya memperlihatkan kecenderungan lebih indvidualistis dan merasa acuh terhadap sesame. Oleh karena itu, penting untuk meningkatkan kesadaran kolektif masyarakat Desa Talagasari agar kegiatan ini berjalan dengan lancar.

Kedua, Tingkat perceraian di Desa Talagasari cenderung tinggi dengan dibuktikan hampir setiap hari ada masyarakat meminta surat pengantar untuk ke pengadilan agama. Dalam artian indeks kerawanan menuju perceraian bagi rumah tangga masyarakat Desa Talagasari cenderung dalam posisi rentan mengalami peningkatan.
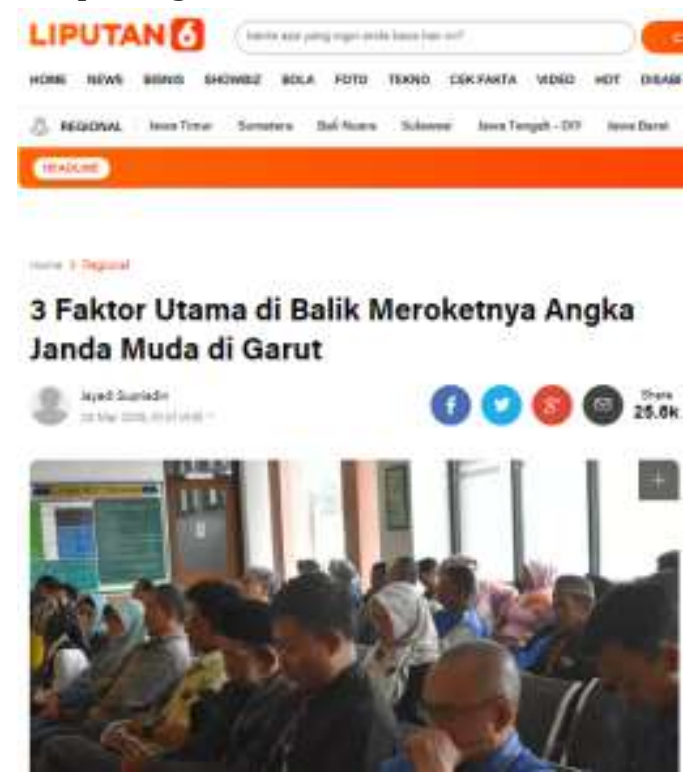

Gambar 1. Cuplikan berita online kondisi sosial masyarakat Kab. Garut

Ketiga, Minimnya pengetahuan para janda terkait hak-hak pasca perceraian, sehingga kondisinya terkesan diterlantarkan. Pasca perceraiannya, rata-rata para janda kembali tinggal 
serumah dengan orang tuanya. Berikut juga dengan anak-anaknya, bahkan kebanyakan anakanaknya sampai disekolahkan oleh kakek dan neneknya, mengingat para janda rata-rata tidak berdaya secara fnansial sehingga harus bekerja menjadi buruh pabrik untuk menutupi kebutuhan ekonomi.

Keempat, Dari segi permasalahan yang dihadapi oleh para anak-anak, keterbatasan area fasilitas publik ruang bermain anak juga menjadi kendala para anak-anak korban rusaknya hubungan rumah tangga orang tuanya menjadi tidak memiliki media untuk memulihkan trauma.

Kelima, Klien yang ditangani oleh LASMA rata-rata terfokus pada perkara sengketa ekonomi syariah, sengketa hukum keluarga dalam artian perceraian baik cerai talak maupun cerai gugat, harta gono-gini dan penetapan ahli waris. Kemudian LASMA secara prodeo atau perkara cumacuma juga menerima dari berbagai wilayah di Jawa Barat. Kebanyakan yang kami terima adalah perkara cerai gugat. Hal ini, menjadi cerminan bahwa istri lebih dominan dalam mengajukan gugatan. Rata-rata alasan perceraian yang diajukan adalah karena alasan ekonomi dan penelantaran. Alasan perceraian diatas menunjukan istri berada pada posisi yang kurang begitu berdaya.

Dari hasil FGD bersama stakeholder ini kemudian dikembangkan dalam bentuk penyusunan desain pendampingan sebagaimana tertuang dalam Bab III di atas. Ketika penulis melakukan survey untuk mengidentifikasi kebutuhan para masyarakat dampingan, terdapat perbedaan minat dalam memilih kegiatan pendampingan bagi janda dan anak-anak, maka penulis dengan terlebih dahulu berkoordinasi dengan aparatur pemerintahan desa melakukan analisis kebutuhan pendampingan secara terpisah dengan harapan lebih fokus dalam pemberdayaannya. Adapun hasil assesment terhadap masyarakat dampingan, dari beberapa kegiatan yang ditawarkan oleh penulis sebagai bagian dari program dampingan yang akan dilaksanakan dapat diperhatikan pada tabel rincian kegiatan berikut ini:

Tabel 1. Hasil assesmen minat masyarakat dampingan

\begin{tabular}{|c|c|c|c|}
\hline \multirow{2}{*}{ No } & \multirow{2}{*}{ Jenis Kegiatan } & \multicolumn{2}{|c|}{ Alternatif Jawaban } \\
\hline & & Minat & Tidak \\
\hline 1 & Penyuluhan Hukum Terkait Hak-hak & $100 \%$ & $0 \%$ \\
\hline & Perempuan dan Anak Pasca Perce-raian & & \\
\hline 2 & $\begin{array}{l}\text { Pendampingan Pro-ses Perceraian di } \\
\text { Pengadilan Agama }\end{array}$ & $100 \%$ & $0 \%$ \\
\hline 3 & Pelatihan Budi-daya Tanaman Obat Keluarga & $60 \%$ & $40 \%$ \\
\hline 4 & Sosialisasi Bahaya Rentenir & $60 \%$ & $40 \%$ \\
\hline 5 & $\begin{array}{l}\text { Pengadaan Ruang Bermain Anak Be-kerja } \\
\text { sama dengan PAUD }\end{array}$ & $50 \%$ & $50 \%$ \\
\hline
\end{tabular}

Berdasarkan ranking pilihan jenis kegiatan remaja sesuai dengan minat masyarakat dampingan, langkah selanjutnya adalah penulis mendiskusikan kembali dengan stakeholder agar nilai guna dari pendampingan ini mencapai hasil maksimal. Tidak semua alternatif pilihan dilaksanakan jika kurang strategis untuk bisa mengubah cara pandang dan pola kehidupan para masyarakat dampingan. Adapun kegiatan yang dirumuskan melalui proses FGD II penyusunan rencana aksi adalah sebagai berikut: 1) Penyuluhan Hukum Terkait Hak-hak Perempuan dan Anak Pasca Perceraian. 2) Pendampingan Proses Perceraian di Pengadilan Agama.

Dalam merencanakan rencana aksi hingga menjadi jadwal kegiatan pemberdayaan ini, penulis bersama stakeholder mendiskusikan tentang kemungkinan hambatan-hambatan yang muncul pada waktu pelaksanaan kegiatan sehingga telah diantisipasi sejak awal solusi yang dipilih. Tokoh masyarakat dan tokoh agama juga memberikan pertimbangan dan input yang bermanfaat untuk kelancaran kegiatan pen-dampingan ini. 


\section{Pelaksanaan Kegiatan Pendampingan}

Pengabdian menggunakan metode PAR yang bercirikan partisipatif dan menggunakan siklus dampingan, penulis memberikan peluang yang cukup kepada masyarakat dampingan untuk melaksanakan kegiatan-kegiatan yang telah ditetapkan dalam jadwal kegiatan. Melalui kegiatan dalam beberapa siklus ini diharapkan masyarakat dampingan mampu mengubah diri menjadi janda dan anak-anak tangguh yang berkualitas dan tidak mengalami ketergantungan.

\section{Siklus Pertama: Penyuluhan Hukum Terkait Hak-hak Perempuan dan Anak Pasca Perceraian}

Perempuan menjadi bagian yang tidak dapat dipisahkan dalam perjuangan panjang bangsa Indonesia untuk meraih kemerdekaan. Keterlibatan perempuan Indonesia dibuktikan melalui Kongres Perempuan Pertama 22 Desember 1928 yang telah mengukuhkan semangat dan tekad bersama untuk mendorong kemerdekaan Indonesia.

Berbagai persoalan sosial yang saat ini marak terjadi dan berdampak pada kehidupan masyarakat khususnya perempuan dan anak, seperti terjadinya kekerasan, bentuk-bentuk perlakuan diskriminatif menjadi tujuan mewujukan Nawacita dengan menyelaraskan kebijakan pembangunan Pemberdayaan Perempuan dan Pemberdayaan Anak yang tercantum dalam RPJMN 2015-2019.

Peran keluarga menjadi salah satu yang diharapkan dapat menjadi bagian utama / pilar untuk mencegah terjadinya kekerasan melalui penanaman nilai-nilai, karakter dan budi pekerti. Ketahanan keluarga sekaligus menjadi pondasi dalam menerapkan kehidupan harmonis, damai dan religious.

Janda dalam setting budaya masyarakat miskin perkotaan memiliki karakteristik yang spesifik. Masalah individualistik dan relasi yang terbangun dalam kehidupan masyarakat di Desa Talagasari memiliki problem yang beragam. Penyuluhan hukum sebagai peningkatan wawasan bagi para janda ini diharapkan janda mampu memahami persoalan rumah tangga berangkat dari pengalaman mereka, hal-hal yang menarik dalam hidup mereka dan bagaimana mereka memiliki sikap kritis dalam menyikapi masalah serta mampu memotivasi diri untuk menjadi janda berkualitas, memiliki jati diri yang kuat, bertanggung jawab dan mandiri untuk selanjutnya dapat pula membangun kembali mahligai rumah tangga dalam bingkai mitsaqon gholidon untuk yang terakhir kalinya.

Dalam kegiatan penyuluhan yang bertajuk "Penyuluhan Hukum Terkait Hak-hak Perempuan dan Anak Pasca Perceraian" ini diikuti oleh 15 orang peserta perwakilan dari masing-masing RW terdiri dari 4 orang janda dan 11 orang masyarakat umum. Kegiatan diawali dengan identifikasi permasalahan yang menjadi alasan perceraian, merumuskan menurut versi peserta. Pada tahap berikutnya peserta dalam kelompok mengidentifikasi dan mendiskusikan masalah-masalah rumah tangga khususnya di Desa Talagasari dan mengidentifikasi faktor-faktor penyebabnya.

Di antara problem yang mereka temukan dalam eksplorasi melalui diskusi kelompok adalah, pada umumnya masalah rumah tangga yang paling dominan diutarakan oleh peserta adalah masalah keuangan. Gangguan keuangan adalah salah satu masalah rumah tangga yang paling atas. Masalah keuangan bisa menyebabkan masalah besar, karena sebagian besar kebutuhan keluarga bertopang pada ketersediaan uang. Uang bisa merusak rumah tangga dalam banyak bentuk.

Bentuk yang pertama adalah adanya hutang. Hutang bisa timbul, misalnya akibat kekurangan dana untuk mencukupi suatu kebutuhan tertentu. Uang tersebut, bisa dipinjam dari bank, keluarga maupun teman. Parahnya, seringkali seseorang kembali berhutang untuk menutupi hutang lainnya, yang menjadikan hutang menumpuk. Bentuk hutang lainnya adalah penggunaan 
kartu kredit yang tidak sesuai kapasitas, terlebih lagi jika dipakai tanpa sepengetahuan pasangannya. Namun persoalan ini tidak ditemukan pada struktur masyarakat Desa Talagasari.

Permasalahan akibat uang selanjutnya adalah berbeda pendapat soal keuangan. Antara suami dan istri berbeda pendapatnya soal keuangan. Misalnya, suami berpendapat 'uang bisa dicari, nikmati selagi ada', sedangkan istri lebih memilih menabung. Perbedaan lainnya adalah pada kebiasaan menggunakan uang.

Selanjutnya yang dapat menjadi masalah karena terkait dengan keunagan adalah kepemilikan dan pembagian uang. Bukan masalah jika setiap rumah tangga memiliki aturan untuk menyimpan uangnya masing-masing, misalnya, karena memiliki tabungan yang didapat dari orangtua atau memiliki bisnis yang sudah dibangun sendiri sejak sebelum menikah. Uang yang bukan didapat karena sejak berkeluarga seperti ini, tidak jarang menjadi sebab pertengkaran. Untuk mengatasinya, banyak pasangan yang membuat surat perjanjian nikah yang diresmikan ke pihak berwenang. Kemudian terkait pembagian uang, suami memercayakan penghasilannya untuk diurus oleh istri, atau suami hanya memberi jatah tertentu pada istri untuk kebutuhan rumah, adalah hak masing-masing rumah tangga. Namun sebaiknya, hal ini sudah dibicarakan dan disepakati bersama sejak awal.

Masalah lainnya terangkum dalam adanya perselingkuhan, terjadi kekerasan dalam rumah tangga, kurangnya keharmonisan karena ketidakcocokan, tidak adanya keturunan dan terkait pekerjaan.

Permasalahan pemenuhan hak-hak mantan istri dan anak pasca perceraian menjadi penting adanya. Dimulai dari pentingnya mengetahui hak-hak tersebut agar para mantan istri tidak merasa tertipu dan diterlantarkan. Pengetahuan inilah hakikatnya sebaik-baiknya perlindungan.

Penulis menyampaikan materi mengenai poin-poin penting hak-hak perempuan pasca perceraian diantaranya adalah putusan hakim pengadilan agama rata-rata menyangkut hak-hak perempuan, disimpulkan sebagai berikut: (1). Kasus perkara cerai gugat maupun cerai talak dengan putusan verstek tidak memuat hak-hak istri, yaitu anggapan hakim tidak boleh memutuskan perkara di luar materi gugatan (ultra petitum) sehingga hakim tidak memiliki keberanian untuk menetapkan/menjamin secara hukum hak-hak perempuan pasca perceraian seperti mut'ah, hak asuh anak, atau hak harta gono gini jika tidak menjadi materi gugatan. (2). Kasus perkara cerai gugat tidak terdapat satupun gugatan mengenai haknya (istri). Meskipun hakim memiliki hak ex oficio dalam menentukan hak-hak perempuan (istri) baik diminta maupun tidak diminta, namun hakim berdasarkan hasil riset pendahuluan di pengadilan-pengadilan agama diantaranya Pengadilan Agama Depok dan Pengadilan Agama Cimahi hanya pada kasus yang penyebab perceraian adalah suami dan istri tidak bersedia diceraikan, maka hakim menggunakan haknya secara ex oficio menghukum suami untuk memberikan mut'ah sesuai dengan kemampuan dan kelayakan. (3). Pada putusan rekonvensi, secara jelas disebutkan hakhak istri di dalam putusan hakim yaitu nafkah iddah, mut'ah, nafkah lampau, dan biaya anak.

Secara normatif, hak ekonomi perempuan cerai telah dijamin dalam UU Perkawinan dan KHI. Hak itu meliputi: Pelunasan maskawin jika belum dibayar tunai, Penggantian nafkah dimasa lampau yang belum dibayarkan, Nafkah iddah 3 (tiga) bulan, Uang mut'ah (penghiburan dari suami atas perce-raiannya) sejumlah yang disepakati, Hak pemeliharaan anak sampai usia dewasa, dan Semua hak-hak ini secara normative merupakan hak istri dan anak yang harus dipenuhi suaminya kecuali jika terbukti istri melakukan nusyuz (pembangkangan).

Namun dalam implementasinya, tidak minim masalah. Ada beberapa kendala dalam mengeksekusi pembebanan nafkah yang telah diputuskan oleh majelis hakim yang menjadikan lemahnya perlindungan terhadap hak-hak perempuan dan anak pasca perceraian, diantaranya: a) Mantan suami meninggalkan tempat kediaman, b) Suami tidak mempunyai penghasilan atau 
tidak menentu penghasilannya, dan c) Suami tidak mempunyai harta yang ditinggalkan sebagai pengganti nafkah.

Padahal seyogyanya, ada kelenturan dalam kaidah hukum jika dikaitkan dengan prinsip ex aequo et bono, yang biasanya termaktub dalam tuntutan subsidair. Apabila Pengadilan Agama berpendapat lain, mohon perkara ini diputus menurut hukum dengan seadil-adilnya. Artinya, prinsip ini memberikan keleluasaan bagi para hakim untuk menggali hukum seluas-luasnya demi menegakkan keadilan. Karena bagaimanapun hakim bukan semata-mata corong UU, namun juga sebagai penafsir dan penemu hukum. Dalam konteks inilah kemampuan hakim untuk menelusuri dan mengungkap fakta hukum menjadi relevan untuk terus digali dan dikembangkan dalam rangka pemberdayaan hakim yang sensitif terhadap nilai-nilai luhur keadilan bukan semata-mata nilai luhur hukum.

Meskipun tindakan ultra petitum yang dilakukan hakim melanggar the principal the rule of law, Mahkamah Agung pernah membuat putusan yang menegaskan bahwa ultra petitum dapat dibenarkan jika masih dalam kerangka yang sejalan dan serasi dengan inti gugatan (Harahap, 2005). Dalam hal ini, persoalan hak iddah atau hak asuh anak di bawah umur menurut penulis merupakan hak yang melekat pada perempuan pasca putusnya perkawinan yang dapat diputus sekaligus. Hakim Pengadilan Agama Depok menuturkan bahwa sesungguhnya hakim secara ex officio karena jabatannya dapat memutus lebih dari apa yang dituntut pemohon jika hakim memandang hal tersebut membawa pada kemaslahatan asalkan putusan penyebab perceraian berasal dari suami.

Adapun faktor penyebab lemahnya perlindungan hak perempuan pasca perceraian khususnya dalam segi cerai talak antara lain: pertama, tidak ada aturan yang tegas dan jelas terhadap suami yang tidak melaksanakan ikrar talak sehingga menimbulkan ketidakpastian hukum, dalam perkara cerai talak ternyata tidak dapat menjamin hak-hak nafkah istri dapat dilaksanakan, hal ini dikarenakan tidak ada aturan hukum yang tegas terhadap pemohon (suami) yang tidak melaksanakan ikrar talak, sehingga hukum belum dapat meciptakan kepastian. Kedua, putusan yang tidak bisa dilaksanakan eksekusi. Ketika suami enggan melaksanakan ikrarnya dengan alasan pembebanan nafkah yang terlalu besar, maka dapat berakibat penetapan ikrar talak gugur dan status para pihaknya tetap utuh sebagai suami-istri yang sah, sehingga istri tidak bisa mengajukan eksekusi atas hak nafkah tersebut. Hak nafkah yang dituntut istri dapat terwujud jika ikrar talak sudah dilaksanakan oleh suami. Ketiga, rendahnya tingkat kesadaran hukum dan pengetahuan hukum di masyarakat. Sedangkan upaya hukum yang dapat dilakukan termohon pasca gugurnya kekuatan penetapan ikrar talak secara tegas dalam Undang-Undang tidak mengaturnya, sehingga yang dapat dilakukan termohon agar statusnya jelas karena digantung oleh pemohon adalah mengajukan gugat cerai. Hal inilah yang mengakibatkan tidak jelasnya pemenuhan hak nafkah istri yang dituntutnya dalam perkara cerai talak yang diajukan pemohon. Demi terwujudnya kepastian hukum, maka perlu adanya aturan yang tegas khususnya untuk pihak pemohon yang tidak bersedia melakukan sidang ikrar talak dan perlu juga adanya sanksi terhadap pemohon yang menelantarkan termohon pasca gugurnya penetapan ikrar talak tersebut.

Pada siklus pertama ini, penulis melakukan pengamatan di seputar pemikiran dan ide-ide peserta dalam membahas tema yang tersedia, antusiasme mereka dalam berdiskusi, rumusan konsep rumah tangga ideal dan solusi atas problem rumah tangga. Pengabdi juga melakukan refleksi terhadap kegiatan yang telah dilakukan dengan memberikan waktu khusus kepada peserta untuk memberikan komentar dan rekomendasi untuk perbaikan kegiatan berikutnya.

Beberapa hambatan pelaksanaan kegiatan pada siklus pertama ini antara lain beberapa peserta datang terlambat, dilaksanakan pada hari kerja sehingga waktu dan pesertanya terbatas, 
peserta masih malu-malu mengemukakan pendapat karena kegian seperti ini belum pernah dilaksanakan di kalangan mereka. Berdasarkan hambatan ini, penulis memberikan saran untuk rancangan kegiatan selanjutnya dilaksanakan pada hari libur agar waktu yang tersedia cukup untuk berdiskusi.

\section{Siklus Kedua: Pendampingan Proses Perceraian di Pengadilan Agama}

Penulis mendapat kesempatan untuk mendampingi klien Lembaga Advokasi Syariah Mathlaul Anwar dalam proses perceraian di Pengadilan Agama Soreang dan Sumedang. Pada siklus ini, penulis dan LASMA sepakat melaksanakan pendampingan hanya untuk perkara prodeo saja.

Proses prodeo ini sebelum diterbitkan Peraturan Mahkamah Agung (PERMA) No. 01 Tahun 2014 tentang Pedoman Pemberian Layanan Hukum Bagi Masyarakat Tidak Mampu di Pengadilan. Persayaratan yang harus dipenuhi oleh pemohon prodeo yaitu membawa Surat Keterangan Tidak Mampu (SKTM) yang dikeluarkan oleh kepala desa/lurah dan diketahui oleh camat setempat serta membawa satu kartu tunjangan sosial lainnya seperti BPJS, BLT dan sejenisnya.

Klien yang didampingi dalam proses perceraian ini adalah:
1. Nama
: Ai Linda Santika Binti Saepudin
$\begin{array}{lll}\text { Umur } & : \text { SLTP } \\ \text { Pendidikan } & : \text { Islam }\end{array}$
Agama : Ibu Rumah Tangga
Pekerjaan : Kp. Junti Hilir, RT/RW 01/03, Kecamatan Katapang, Kabupaten
Alamat : Bandung.
Alasan Perceraian : - Suami kurang bertanggung jawab terkait nafkah rumah tangga;
- Suami gampang marah dan kurang memiliki kepedulian terhadap keluarga
Pengajuan Gugatan : 03 September 2019
Nomor Register : $\quad$ 5725/Pdt.G/2019/PA.Sor
2. Nama : Wiliawati Binti Tarjat
Umur : $\quad 40$ Tahun
Pendidikan : SLTA
Agama : Islam
Pekerjaan : : Ibu Rumah Tangga
Alamat : Jalan Cut Nyak Dien Gg. Anggapraja No. 02, RT/RW 01/07,
Kelurahan Regol Wetan, Kecamatan Sumedang Selatan, Kabupaten Sumedang.
Alasan Perceraian : - Suami kurang bertanggung jawab terkait nafkah rumah tangga;
- Suami malas bekerja serta tidak ada keinginan untuk mencari kerja;
- Selama 2 tahun 1 bulan, suami sudah tidak memberikan nafkah.
Pengajuan Gugatan : 03 September 2019
Nomor Register $\quad: \quad 3082 /$ Pdt.G/2019/PA.Smd
3. Nama : Wiwi Widaningsih Binti Yaya
Umur : 26 Tahun
Pendidikan : SLTP
Agama : Islam
Pekerjaan : Ibu Rumah Tangga
Alamat : Dusun Marasa, RT/RW 03/07, Desa Cisalak, Kecamatan Cisarua, 


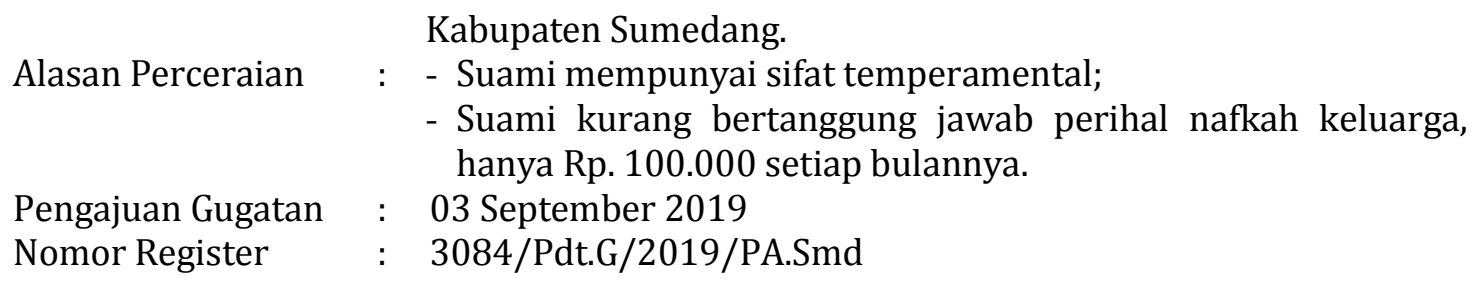

Penulis kemudian menjelaskan kepada para klien terkait mekanisme beracara bagi pihak penggugat / pemohon yang mengajukan perkara prodeo adalah sebagai berikut:

1. Pihak penggugat/pemohon yang hendak mengajukan perkara dengan prodeo, maka harus mengajukan permohonan perkara prodeo kepada majelis hakim dengan ketentuan :

a. Permohonan perkara secara prodeo ditulis menjadi satu dalam surat gugatan/ permohonan.

b. Dalam permohonan tersebut disebutkan alasan-alasan untuk berperkara secara prodeo.

2. Penggugat/pemohon mengajukan gugatan/permohonan ke pengadilan melalui Meja I, kemudian kasir pengadilan tingkat pertama akan mengeluarkan kwitansi Surat Kuasa Untuk Membayar (SKUM) sebesar Rp. 0,00 (nol rupiah).

3. Setelah berkas perkara diterima oleh ketua Pengadilan Agama, maka ketua Pengadilan Agama menunjuk majlis hakim untuk menangani perkara tersebut Penetapan Majelis Hakim ( $\mathrm{PMH}$ ).

4. Majelis hakim menetapkan hari sidang dan memerintahkan juru sita untuk memanggil penggugat/pemohon dan tergugat/termohon.

5. Majelis hakim memerintahkan kepada kuasa pengguna anggaran agar mengeluarkan biaya panggilan masing-masing satu kali biaya panggilan untuk penggugat/pemohon dan tergugat/termohon dalam bentuk sebuah instrumen, yang selanjutnya pula kuasa pengguna anggaran/pansek mengeluarkan perintah kepada bendahara pengeluaran juga dalam bentuk sebuah instrumen.

6. Petugas buku induk keuangan perkara, petugas/pemegang buku jurnal keuangan perakara, dan petugas/pemegang buku kas pembantu mencatat penerimaan tersebut di dalam bukubuku mereka sebagai penerimaan panjar pertama. Pada hari sidang yang telah ditentukan, majelis hakim sebelum memeriksa pokok perkara, terlebih dahulu memeriksa permohonan beracara secara cuma-cuma tersebut di dalam persidangan.

7. Apabila permohonan beracara secara prodeo terbukti dan permohonan tersebut dikabulkan, maka majelis hakim menjatuhkan putusan sela yang dimuat secara lengkap di dalam berita acara persidangan.

8. Salinan amar putusan sela tersebut diserahkan oleh majelis hakim kepada kuasa pengguna anggaran guna pembayaran perkara oleh negara.

9. Pansek menyerahkan salinan amar putusan itu kepada bendahara rutin dengan perintah agar mengeluarkan sejumlah uang panjar sebesar Rp. 531.000.,- (lima ratus tiga puluh satu rupiah) dikurangi jumlah uang yang sudah dikeluarkan sebagai biaya panggilan pertama.

10. Dengan diterimanya uang panjar dari bendahara rutin, kasir mengeluarkan kwitansi SKUM sejumlah uang yang diterima.

11. Petugas buku induk keuangan perkara, petugas/pemegang buku Jurnal keuangan perkara, dan petugas/pemegang buku kas pembantu mencatat penerimaan tersebut di dalam bukubuku mereka sebagai penerimaan panjar kedua.

12. Apabila permohonan prodeo tidak terbukti, majelis hakim menjatuhkan putusan sela yang berisi memerintahkan penggugat/pemohon untuk membayar biaya perkara sesuai yang ditaksir oleh meja pertama, jeda waktu pembayaran diberikan selama satu bulan. 
13. Apabila penggugat/pemohon membayar biaya perkara sesuai perintah dalam putusan sela pengadilan, kasir wajib mengembalikan uang negara tersebut ke negara.

14. Setelah putusan akhir dibacakan, apabila terjadi kelebihan biaya perkara, kasir wajib mengembalikan kelebihan biaya perkara tersebut kepada kas negara.

15. Setelah putusan akhir dibacakan, apabila biaya perkara ternyata kurang, majelis hakim dapat memerintahkan kepada kuasa pengguna anggaran untuk mengeluarkan biaya perkara tambahan yang diperlukan dengan menggunakan instrumen.

16. Seluruh biaya perkara yang tercantum dalam putusan pengadilan, harus sama dengan biaya yang dikeluarkan negara melalui DIPA Pengadilan Agama.

Sesudah persidangan tentang ditolak dan tidaknya suatu permohonan prodeo, dan jika permohonan prodeo diterima maka dilanjutkan dengan sidang kedua, proses jalannya sidang kedua ini sama seperti proses jalannya perkara biasa.

Sedangkan prosedur atau mekanisme setelah terbitnya PERMA No. 01 Tahun 2014 tentang pedoman pemberian layanan hukum bagi masyarakat tidak mampu di pengadilan adalah sama seperti ketentuan diatas, tapi yang berbeda adalah tentang surat permohonan prodeo yang didaftarkan bersamaan dengan surat gugatan, meja satu bertugas meneliti berkas-berkas, kemudian panitera memeriksa apakah layak atau tidak layak suatu permohonan prodeo itu diterima, jika layak maka ketua Pengadilan Agama membuat surat penetapan pembebasan biaya. kemudian dilanjutkan dengan sidang seperti perkara biasa. Dalam surat penetapan pembebasan biaya terdapat persyaratan yang dibawa oleh pemohon prodeo yakni Surat Keterangan Tidak Mampu (SKTM) yang dikeluarkan oleh kepala desa/lurah yang diketahui oleh camat setempat dan kartu Jaminan Kesehatan Sosial Masyarakat (Jamkesmas).

Jika sebelum PERMA ini diterbitkan, penentuan layak dan tidak layaknya surat permohonan prodeo tersebut ditetapkan pada sidang pertama.

Hasil dari wawancara penulis dengan salah satu pemohon prodeo di Pengadilan Agama Sumedang bahwa persyaratan yang dibuat oleh Pengadilan Agama Sumedang tentang perkara prodeo sejauh ini dirasa dapat dengan lancar pemohon prodeo penuhi, adanya keharusan melampirkan SKTM yang harus diketahui oleh camat setempat, juga dapat pemohon lengkapi. Setelah pendaftaran sudah selesai maka penggugat diberitahu hari dan tanggal dilaksanakannya persidangan. Hanya saja, berdasarkan hasil wawancara penulis jarak waktu antara hari pendaftaran dengan hari persidangan berjarak tiga minggu lebih, hal ini membuat pemohon merasa sangat menunggu lama untuk menyelesaikan perkaranya di Pengadilan Agama Sumedang (Wiliawati, 2019). 


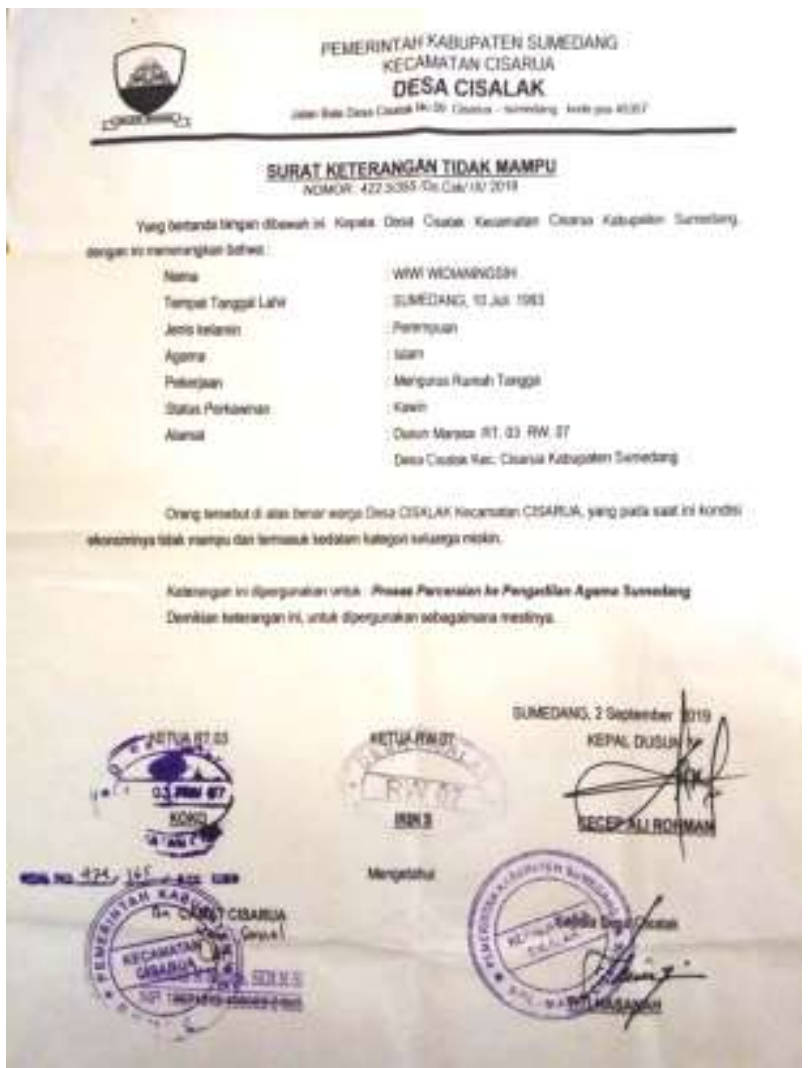

Gambar 2. Format SKTM khusus untuk proses perceraian di Pengadilan Agama Sumedang

Ketika penggugat atau pemohon perkara prodeo tidak mengerti cara membuat surat gugatan dan permohonan prodeo, maka LASMA pun membantu pemohon atau penggugat untuk membuat surat gugatan dan permohonan prodeo.

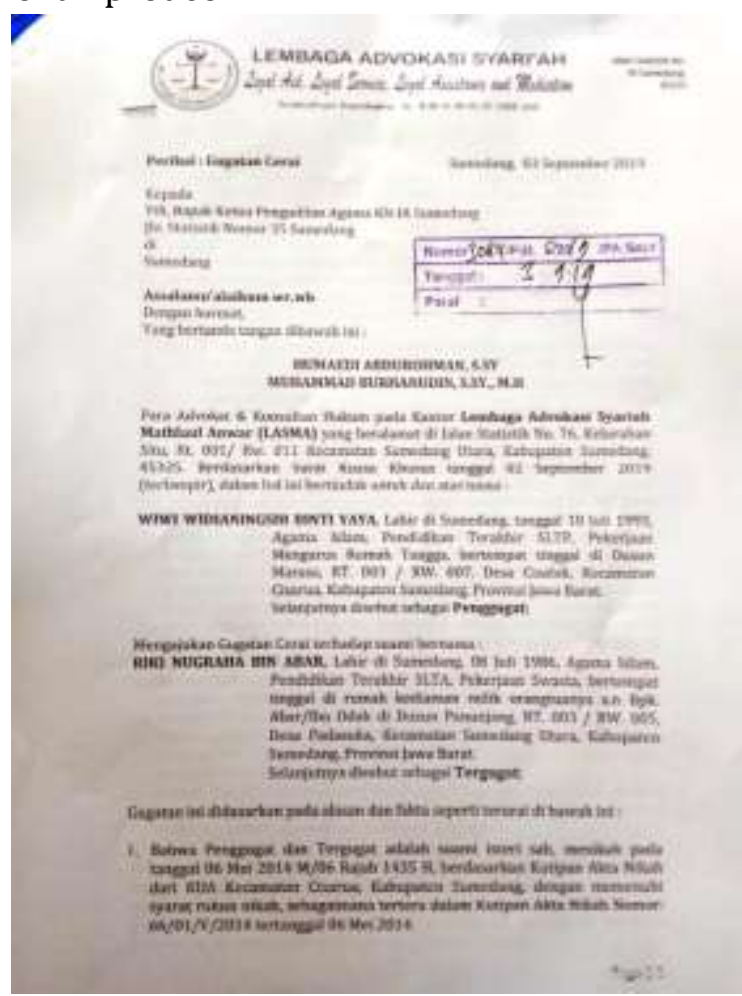

Gambar 3. Surat gugatan yang sudah diregister 


\section{Kendala yang dihadapi \\ Kesulitan koordinasi dengan aparat setempat}

Kesibukan masyarakat dampingan dengan mata pencaharian bermacam-macam menyebabkan seolah-olah kehidupan mereka diatur oleh waktu. Warga masyarakat Desa Talagasari antara lain bekarja sebagai pedagang, buruh pabrik, pegawai toko, PNS dan lain-lain, menyebabkan waktu mereka lebih banyak dihabiskan di tempat kerja. Aparat setempat seperti ketua RW, Ketua RT, tokoh agama dan masyarakat juga mempunyai pekerjaan dan aktivitas sosial yang beragam dan menyita banyak waktu sehingga untuk berkoordinasi dengan penulis mengalami kesulitan. Kegiatan penulis di kampus juga cukup padat mulai dari mengajar, membimbing mahasiswa, mengoreksi tugas-tugas dan karya ilmiah mahasiswa, dan aktivitas rutin kantor.

\section{Kurang berminat mengikuti kegiatan}

Kegiatan pengabdian ini dimulai dengan pendektan buttom up dengan karakteristiknya menggali kebutuhan dari masyarakat dampingan. Proses ini memerlukan waktu yang cukup untuk bisa bertemu secara intens dengan subyek dampingan. Masyarakat Desa Talagasari yang menjadi basis binaan sehari-hari beraktivitas sebagai pekerja, pedagang, dan lain sebagainya. Aktivitas tersebut tentu saja menyedot banya energi para peserta, sehingga kegiatan penyuluhan hukum yang diselenggarakan terkesan minim peminat.

\section{Dampak Politik uang pilkada, pilpres dan pileg}

Semenjak era reformasi dan kran demokrasi dibuka, sistem pemilihan anggota legislatif, presiden maupun kepala daerah masyarakat memilih secara langsung, banyak pembagian sembako, uang dan fasilitas yang masuk di masyarakat pemilih, hal ini berdampak pada mental masyarakat yang semakin materialistik. Setiap ada orang lain seperti kegiatan penelitian sering dipahami sebagai orang-orang mempunyai kepentingan politik yang berujung pada membagian materi. Ketika penulis mengalami kesulitan berkoordinasi dan mengumpulkan subjek binaan, ada saran dari masyarakat bahwa sebaiknya bagi-bagi uang atau materi dalam bentuk apa saja sebelum mereka diajak bergerak. Fenomena ini penulis pahami sebab mindset masyarakat menjadi demikian bukan sebagai watak dasar mereka, hal ini sebagai dampak permainan politik yang membuat kondisi mental mereka menjadi berubah.

\section{Strategi Pemecahan Masalah}

Untuk menghadapi kendala yang ditemukan di lapangan di atas, penulis menggunakan strategi pemecahan masalah sebagai berikut:

Pertama, Untuk mengatasi kesulitan koordinasi dengan stakeholder, penulis memaksimalkan penggunaan HP untuk komunikasi agar kegiatan tidak mengalami penundaan. Disamping itu penulis mengoptimalkan peran dan fungsi kepala dusun dibawah koordinasi langsung Kepala Desa yang bertanggungjawab selama kegiatan pengabdian ini berlangsung untuk mengkondisikan kegiatan penyuluhan dan koordinasi antar peserta dalam proses pendampingan.

Kedua, Lemahnya minat masyarakat dampingan terhadap kegiatan pemberdayaan, Penulis mencoba memecahkan masalah dengan memberikan motivasi, mengubah metode dalam penyuluhan yang asalnya lebih banyak menjelaskan, diubah menjadi diskusi-diskusi kelompok dan permainan.

Ketiga, Politik uang yang digunakan oleh tim sukses atau politisi untuk mengumpulkan suara pada momen pilkada, pilpres maupun pileg telah berdampak rusaknya mental masyarakat. Penulis mengantisipasi macetnya kegiatan akibat hambatan ini dengan cara menjelaskan maksud pengabdian yang dilaksanakan, memberikan penyadaran khususnya kepada para janda tentang 
pentingnya pengetahuan agar senantiasa dapat digunakan untuk memperjuangkan hak-hak untuk perubahan nasib mereka sendiri agar menjadi lebih berkualitas, dan memberikan motivasi bahwa setiap orang akan berubah jika dirinya sendiri yang berupaya untuk mengubahnya. Dengan motivasi ini masyarakat menyadari bahwa tidak setiap tetes keringat untuk kebaikan harus diberi imbalan materi, sebab amal shaleh yang ikhlas jauh lebih bermakna dalam kehidupan

\section{Efektifitas Perlindungan Hak-hak Perempuan dan Anak Pasca Perceraian Melalui Kegiatan Penyuluhan Hukum}

Janda sering dilabeli stereotype yang cenderung kurang baik. Labeling negatif tersebut, tidak bisa dipungkiri memang muncul pada sebagian atau bahkan mayoritas janda, karena merupakan cerminan jiwa mereka yang bergejolak setelah dihadapkan pada permasalahan rumah tangga yang cenderung tidak selesai mereka jalani sehingga harus terjadi perpisahan. Mereka berada pada masa transisi dari posisi terikat dengan hadirnya suami menjadi pribadi bebas setelah bercerai. Pada masa transisi ini, mereka berusaha mencari formula yang sesuai dengan diri mereka dalam mengaktualisasikan diri mereka di masyarakat. Oleh karena itu, tidak bisa menyalahkan sepenuhnya perilaku janda yang kadang-kadang aneh dan tidak bisa dikendalikan karena merupakan cerminan batin mereka.

Fenomena ini dapat disebabkan oleh beberapa faktor, yaitu: 1).Identitas negatif; 2). Kontrol diri yang rendah; 3). Usia; 4). Status sosial ekonomi yang rendah, 5). Pengaruh teman sebaya, 6). Faktor orang tua (tidak adanya pengawasan, rendahnya dukungan, dan penerapan disiplin yang tidak efektif), dan 7). Kualitas lingkungan sekitar (perkotaan, tingkat kriminalitas tinggi dan tingkat mobilitas tinggi). (Steinberg, 2001)

Dari segi relasi sosial, ada masa transisi sosial (social transition) kebiasaan janda yang menonjol adalah meningkatnya alokasi waktu yang mereka pergunakan untuk berkumpul dengan teman sebaya mereka. Pentingnya teman sebaya pada masa transisi awal ini berbanding lurus dengan perubahan kebutuhan mereka terhadap keintiman. Tema pembicaraannya lebih kepada gaya hidup.

Subjek dampingan yakni masyarakat Desa Talagasari secara umum juga mengalami perubahan disebabkan masa transisi ini. Untuk melakukan analisis perubahan pada subjek dampingan ini penulis mencoba untuk menggunakan dua teori, yaitu: 1) Teori kognitif pendekatan psikologi, dan 2) Teori strukturasi pendekatan sosial

Teori Kognitif lebih menekankan kepada pentingnya pikiran subjek dampingan yang mereka sadari dan mereka sengaja. Berbeda dengan teori psikoanalisis yang lebih menekankan pentingnya pemikiran yang tidak disadari oleh para subjek dampingan. Teori kognitif ini ada dua macam; teori perkembangan kognitif yang dipopulerkan oleh Jean Piaget (1896-1980), seorang psikolog Swiss dan teori pemrosesan informasi. Dalam pandangan Piaget para remaja merekonstruksi pemikiran mereka sendiri secara aktif. Pikiran mereka tidak hanya berasal dari lingkungan di mana mereka hidup, melainkan mereka memunculkan gagasan baru dari dan dalam rangka menyesuaikan dengan lingkungan mereka. Piaget mengemukakan tahapantahapan metode berpikir dalam menghadapi lingkungan mereka, yaitu: tahap sensorimotorik, tahap praoperasional, tahap operasional konkrit, dan tahap operasional formal. Sedangkan teori pemroresan informasi adalah berhubungan dengan bagaimana seorang individu remaja memproses informasi mengenai dunianya, bagaimana informasi masuk pikiran, disimpan dan ditransformasikan, dan bagaimana informasi tersebut diambil kembali untuk melakukan aktivitas kompleks seperti dalam memecahkan masalah dan penalaran. (Steinberg, 2001) 
Para janda masyarakat Desa Talagasari sebagai subjek dampingan, keterbatasan SDM yang disebabkan keterbatasan pendidikan, lilitan kesulitan ekonomi, dan lingkungan masyarakat marjinal secara kultur maupun struktur sehingga membentuk maindset mereka yang teralienasi dari masyarakat pada umumnya yang dikonsepsikan sebagai masyarakat yang lebih berhasil dalam membina hubungan rumah tangga, namun dalam realitasnya jauh berbeda. Karena itu entri point upaya pengabdian ini adalah mengubah mindset mereka bahwa kehidupan ini dinamis, berubah, penuh tantangan, dan kompetitif. Perubahan dimaksud harus dimulai dari diri para janda itu sendiri dengan mengaktifkan pengalaman-pengalaman dan stok of knowledge tentang masih adanya hak-hak bagi mereka setelah perceraian.

Untuk mengubah mindset para janda bukan hal yang mudah. Berbagai dimensi turut membentuk mindset dan kepribadian mereka. Keluarga merupakan pusat pendidikan pertama dan utama bagi setiap orang. Kebiasaan yang ditanamkan kepada oleh suami maupun orang tua kepada anak sangat menentukan cara pandang, cara berfikir dan bertingkah laku di masyarakat. Kondisi masyarakat khususnya di Desa Talagasari yang tidak banyak tersentuh pembinaan, sedangkan mereka juga mempunyai potensi yang bisa dikembangkan, menyebabkan mereka mengalami krisis identitas. Krisis identitas ini terkait pula dengan konsep diri yang rendah (negatif) yang menjadikan seseorang pesimis dalam menghadapi kenyataan hidup. Dalam teori tingkah laku, berpendapat bahwa tingkah laku para janda dapat diobservasi dan dipelajari berdasarkan pengalaman-pengalaman mereka dengan lingkungan. Tingkah laku mereka merupakan interaksi antara kognisi mereka dengan lingkungannya. Teori yang mempelajari tingkah laku ini ada dua; teori behaviorisme yang dipopulerkan oleh Skinner dan teori belajar sosial (social learning theory). Teori behaviorisme ini menekankan kepada studi ilmiah terhadap respons tingkah laku terhadap lingkungan mereka dan menetapkan tingkah laku yang sesuai dengan lingkungan mereka. Oleh karena itu, perkembangan pada diri janda bisa dipelajari dan dianalisis; dan dapat dilihat pula bahwa tingkah laku para janda akan berubah apabila lingkungan di sekitar mereka juga berubah.

Adapun teori belajar sosial menekankan bahwa tingkah laku, lingkungan, dan kognisi sebagai faktor utama perkembangan masyarakat.

Berdasarkan teori tersebut, penulis mengamati tingkah laku para janda yang menampilkan simbol-simbol sosial sebagai indikator apa sebenarnya yang terjadi dalam diri mereka. Kemudian treatment apa saja yang diperlukan berdasarkan masalah mereka. Untuk itu, pendampingan pemberdayaan bagi janda dengan karakteristik demikian ini diperlukan strategi buttom up dan dialogis. Melalui diskusi, sharing pengalaman dan mencoba membuka diri dan kenyataan sosial di seputar kehidupan mereka. Menampilkan model sebaya yang mempunyai pengalaman yang hampir sama, sehingga sikap empati model dapat menyedot perhatian subyek dampingan karena merasa senasib, akhirnya mereka sedikit mau membuka diri dan berbagi problem yang mereka hadapi.

Dengan demikian perubahan yang terjadi pada kegiatan penyuluhan dan pendampingan ini antara lain subyek dampingan secara efektif mampu: a) Mengidentifikasi masalah sosial di lingkungan mereka sendiri khususnya yang berkaitan dengan rumah tangga; b) Mengetahui hakhak sebagai istri maupun mantan istri dan hak-hak anak; c) Berbagi pengalaman yang pernah mereka dapatkan dari kehidupan; d) Memecahkan masalah dengan solusi-solusi yang mereka anggap strategis; dan e) Sedikit mengenal bahwa diri mereka membutuhkan pendampingan dan pemberdayaan. 


\section{Bentuk Upaya Perlindungan}

Penting untuk memberikan pengetahuan kepada para istri bahwa ketidakhadiran pihak suami dalam sidang ikrar talak secara Undang-undang dan KHI mengakibatkan gugurnya kekuatan penetapan izin ikrar talak, sehingga penetapan itu tidak mempunyai daya mengikat lagi kepada suami istri, dengan demikian maka secara hukum status pemohon (suami) dan termohon (istri) kembali sebagai suami istri. Hal ini jelas sangat merugikan kepentingan temohon (istri), lebihlebih termohon dalam cerai talak tidak dapat memaksa pemohon agar melaksanakan ikrar talak.

Tidak hadirnya pemohon dalam pelaksanaan ikrar talak, memang secara mutlak dilaksanakan atau tidak dilaksanakan ikrar tersebut adalah ditangan pemohon (suami), dimana termohon hanyalah diposisikan sebagai objek, artinya tidak dapat memaksa pemohon harus melaksanakan sidang ikrar talak. Kembali terhdap i'tikad pemohon, bila memang beri'tikad baik apapun resikonya semestinya pemohon harus melaksanakannya, karena pemohon sendiri yang mengajukan cerai tersebut. Dengan i'tikad pemohon mengajukan perceraian sudah dapat diartikan bahwa hatinya telah menyatakan mencerai istrinya (termohon), dengan demikian selama proses perceraian berlangsung antara kedua belah pihak sudah tidak ada hubungan yang harmonis lagi, tetapi apabila pemohon (suami) mempunyai i'tikad tidak baik seperti kasus yang dipaparkan diatas, yang pada akhirnya pemohon tidak bersedia melaksanakan sidang ikrar talak dan mengakibatkan gugurnya kekuatan penetapan tersebut.

Akibatnya status termohon (istri) menjadi terombang-ambing dalam arti, cerai talak tidak diurusi atau diperhatikan oleh pemohon (suami), hal ini sangat menambah penderitaan termohon, yang seharusnya mendapatkan perlindungan hukum dengan meminta hak-haknya yang belum terpenuhi sebagai istri, akan tetapi malah penderitaan yang didapat. Terhadap upaya hukumnya tidak ada yang dapat dilakukan istri, menurut keterangan hakim di Pengadilan Agama Kota Depok mengatakan langkah hukum setelah gugurnya kekuatan penetapan ikrar talak adalah pihak istri mengajukan gugatan terhadap suami. Menurut keterangan salah satu Hakim Pengadilan Agama Kota Depok, Amir Syarifuddin, bahwa tidak ada upaya hukum dalam kasus cerai talak yang suaminya enggan melaksanakan ikrarnya karena dalam putusan tersebut sudah berkekuatan hukum tetap. Upaya hukum dapat dilakukan ketika belum sampai berkekuatan hukum tetap, dan harus mengajukan perkara baru. Upaya hukum juga dapat terjadi karena para pihak tidak puas dengan keputusan hakim, hakim dianggap lalai dalam mempertimbangkan beberapa hal, dan adanya kesalahan yang melanggar Undang-undang."

Dalam hal ini putusan sudah berkekuatan hukum tetap lalu gugur karena akibat suami tidak mengikrarkan talaknya, mengakibatkan tidak ada upaya hukum bagi istri, selanjutnya langkah hukum bagi istri adalah mengajukan gugatan terhadap suami, sesuai dengan Pasal 73 ayat (1) Undang-Undang Nomor 7 Tahun 1989 tentang Peradilan Agama yang berbunyi :

"Gugatan perceraian oleh istri atau kuasanya kepada Pengadilan yang daerah hukumnya meliputi tempat kediaman pengguat, kecuali apabila penggugat dengan sengaja meninggalkan tempat kediaman bersama tanpa izin tergugat".

Dengan mengajukan gugatan tersebut Undang-Undang hanya memberikan perlindungan hukum terhadap termohon (istri) dan akibat perceraian sebagaimana ditentukan dalam Pasal 78 Undang-Undang Nomor 7 Tahun 1989 tentang Peradilan Agama yang berbunyi:

"selama berlangsungnya perceraian, atas permohonan penggugat peradilan dapat:1) Menentukan nafkah yang ditanggung oleh suami; 2) Menentukan hal-hal yang perlu untuk menjamin pemeliharaan dan pendidikan anak; 3) Menentukan hal-hal yang perlu untuk menjamin terpeliharanya barangbarang yang menjadi hak bersama suami-istri atau barangbarang yang menjadi hak suami atau barang-barang yang menjadi hak istri". 
Dari data yang penulis peroleh di lapangan, maka penulis berkesimpulan dengan tidak adanya sanksi dan aturan yang tegas terhadap ketidak hadiran pihak pemohon (suami) dalam pelaksanaan sidang ikrar talak, maka pihak termohon (istri) sanagt dirugikan dan adanya diskriminasi hukum antara pemohon dan termohon.

Apabila ditinjau dari teori kesadaran hukum maka, ketika dalam memahami dan melaksanakan putusan pihak pemohon dapat dikatakan tidak sadar hukum, padahal dalam proses persidangan hakim sudah berupaya memberikan keputusan yang seadil-adilnya dengan mempertimbangkan fakta hukum yang terjadi, yakni dengan memerintahkan / menghukum pemohon membayar kepada termohon berupa nafkah iddah, mut'ah dan madiyah. Sedangkan terhadap upaya pihak perempuan dalam mempertahankan hak-haknya juga dapat dikatakan tidak sadar hukum, karena setelah putusan gugur pihak perempuan hanya mengunggu pihak suami membayarkan nafkah-nafkah tersebut, padahal ketika putusan tersebut sudah gugur maka hilang hak-hak istri.

Terlepas dari putusan ini, menurut salah satu hakim Pengadilan Agama Kota Depok, M.Amir Syarifuddin menjelaskan bahwa ketika memang benar istri dan anak ditelantarkan oleh suami maka istri dapat mengajukan langkah hukum ke jalur pidana, dengan delik aduan KDRT sehingga ketika nafkah-nafkah istri dan anak tidak dipenuhi maka suami bisa dipenjara.

Jadi ada dua jalur bagi istri untuk mendapatkan hak-haknya, yaitu melalui jalur perdata dan jalur pidana. Jalur perdata ini dilakukan agar status istri menjadi jelas, maka pihak isti harus mengajukan gugatan baru dan sekaligus dalam gugatan tersebut menyatakan hak-haknya untuk dituntut dan dikabulkan oleh majelis hakim. Sedangkan untuk masalah penelantaran istri dan anak bisa diajukan secara pidana karena melanggar ketentuan dalam Undang-Undang Kekerasan Dalam Rumah Tangga (KDRT) dan Perlindungan Anak.

\section{Faktor Pendukung dan Penghambat Pemenuhan Hak-hak Perempuan dan Anak Pasca Perceraian}

Ketika terjadi perceraian karena talak, seorang suami berkewajiban memberikan sejumlah biaya kepada isteri dan anak-anak yang ditinggalkan. Ada biaya mut'ah, ada kewajiban melunasi mas kawin jika belum lunas, dan ada pula biaya pemeliharaan anak (hadhanah) dan biaya masa tunggu (iddah). Kewajiban memberikan biaya itu dirumuskan dalam UU Perkawinan dan Kompilasi Hukum Islam.

Tetapi dalam praktik, pemenuhan kewajiban tersebut ditunjang oleh berbagai macam faktor. Sebagai faktor pendukung pemenuhan hak-hak perempuan dan anak pasca perceraian diantaanya adalah;

Pertama, Itikad baik dari suami. Tidak ada sanksi bagi suami yang tidak memenuhi nafkah pasca perceraian selain dari teguran. Oleh karena itu, itikad baik dari suami berperan besar dalam implementasi pemenuhan hak-hak perempuan dan anak pasca perceraian.

Kedua, Amar putusan majelis hakim. Dalam cerai talak, kewajiban pemenuhan hak tersebut secara langsung termuat dalam amar putusan majelis hakim. Berbeda dengan pada kasus cerai gugat, pemberian nafkah bagi mantan istri menjadi opsional adanya, jika tidak tercantum dalam gugatan, pembebanan kewajiban nafkah bagi suami menjadi tidak ada. Padahal secara ex-officio hakim dapat saja menetapkan kewajiban nafkah tersebut sepanjang dimaknai sebagai bagian dari pemenuhan keadilan bagi mantan istri dan anak-anaknya.

Ketiga, Suami memiliki pernghasilan dan/atau harta yang cukup untuk memenuhi tuntutan kewajiban. Tidak bisa dipungkiri, adanya harta yang bisa diberikan menjadi faktor penting yang sangat mendukung dalam pemenuhan hak-hak perempuan dan anak pasca perceraian. 
Adapun faktor penyebab yang menghambat perlindungan hak perempuan pasca perceraian khususnya dalam segi cerai talak antara lain:

Pertama, tidak ada aturan yang tegas dan jelas terhadap suami yang tidak melaksanakan ikrar talak sehingga menimbulkan ketidakpastian hukum, dalam perkara cerai talak ternyata tidak dapat menjamin hak-hak nafkah istri dapat dilaksanakan, hal ini dikarenakan tidak ada aturan hukum yang tegas terhadap pemohon (suami) yang tidak melaksanakan ikrar talak, sehingga hukum belum dapat meciptakan kepastian.

Kedua, putusan yang tidak bisa dilaksanakan eksekusi. Ketika suami enggan melaksanakan ikrarnya dengan alasan pembebanan nafkah yang terlalu besar, maka dapat berakibat penetapan ikrar talak gugur dan status para pihaknya tetap utuh sebagai suami-istri yang sah, sehingga istri tidak bisa mengajukan eksekusi atas hak nafkah tersebut. Hak nafkah yang dituntut istri dapat terwujud jika ikrar talak sudah dilaksanakan oleh suami.

Ketiga, rendahnya tingkat kesadaran hukum dan pengetahuan hukum di masyarakat. Sedangkan upaya hukum yang dapat dilakukan termohon pasca gugurnya kekuatan penetapan ikrar talak secara tegas dalam Undang-Undang tidak mengaturnya, sehingga yang dapat dilakukan termohon agar statusnya jelas karena digantung oleh pemohon adalah mengajukan gugat cerai. Hal inilah yang mengakibatkan tidak jelasnya pemenuhan hak nafkah istri yang dituntutnya dalam perkara cerai talak yang diajukan pemohon.

Demi terwujudnya kepastian hukum, maka perlu adanya aturan yang tegas khususnya untuk pihak pemohon yang tidak bersedia melakukan sidang ikrar talak dan perlu juga adanya sanksi terhadap pemohon yang menelantarkan termohon pasca gugurnya penetapan ikrar talak tersebut.

\section{KESIMPULAN}

Berdasarkan pemaparan teori dan analisis diatas, maka penulis dapat mengambil kesimpulan sebagai berikut: Pertama, Perlindungan hak-hak perempuan dan anak pasca perceraian melalui kegiatan penyuluhan hukum demikian secara efektif membuat subyek dampingan mampu: a) Mengidentifikasi masalah sosial di lingkungan mereka sendiri khususnya yang berkaitan dengan rumah tangga; b) Mengetahui hak-hak sebagai istri maupun mantan istri dan hak-hak anak; c) Berbagi pengalaman yang pernah mereka dapatkan dari kehidupan; d) Memecahkan masalah dengan solusi-solusi yang mereka anggap strategis; dan e) Sedikit mengenal bahwa diri mereka membutuhkan pendampingan dan pemberdayaan. Kedua, Bentuk upaya perlindungan yang penulis lakukan adalah dengan melaksanakan kegiatan penyuluhan hukum dan pendampingan pada proses litigasi di Pengadilan Agama Soreang dan Pengadilan Agama Sumedang. Ketiga, Dalam praktiknya, pemenuhan hak-hak perempuan dan anak pasca perceraian ditunjang oleh berbagai macam faktor. Sebagai faktor pendukung pemenuhan hak-hak perempuan dan anak pasca perceraian diantaranya adalah (1) Itikad baik dari suami, (2) Amar putusan majelis hakim yang mencantumkan kewajiban suami terhadap mantan istri ketika terjadi perceraian, dan (3) Suami memiliki penghasilan dan/atau harta yang cukup untuk memenuhi tuntutan kewajiban. Sedangkan faktor penyebab yang menghambat perlindungan hak perempuan pasca perceraian khususnya dalam segi cerai talak antara lain: (1) tidak ada aturan yang tegas dan jelas terhadap suami yang tidak melaksanakan ikrar talak sehingga menimbulkan ketidakpastian hukum, (2) putusan yang tidak bisa dilaksanakan eksekusi. (3) rendahnya tingkat kesadaran hukum dan pengetahuan hukum di masyarakat. 
Aziz Sholeh, Dian Rachmat Gumelar, Aah Tsamrotul Fuaah - Pendampingan Hak-Hak Perempuan....

\section{DAFTAR PUSTAKA}

Abdul Azhim Badawi. 2008. Fiqih nikah praktis, Jawa Barat: Salwa Press.

Abdul Aziz Muhammad Azzam. 2009. Fiqih Munakahat. Jakarta: AMZAH. Cet. I.

Abdul Manan. 2005. Penerapan Hukum Acara Perdata Di Lingkungan Peradilan Agama. Jakarta: Kencana.

Adnan Buyung Nasution, 1981. Bantuan Hukum Di Indonesia. Cet. 3. Jakarta; LP3ES.

Ahmad Warson Munawwir. 2002. Kamus al Munawwir Arab-Indonesia Cet. XX. Surabaya: Pustaka Progresif.

Ahmad Mahmudi, SH. Kuliah Pengantar Tentang Pembangunan dan Pemberdayaan Masyarakat.

Amir Syarifuddin. 2011. Hukum Perkawinan Islam Di Indonesia: Antara Fiqh Munakahat Dan Undang-Undang Perkawinan. Cet.I. Jakarta: Kencana.

2009. Hukum Perkawinan Islam di Indonesia Cet. III. Jakarta: Kencana Prenada Media Group.

Cik Hasan Bisri. 2001. Penuntun Rencana Penelitian dan Penulisan Skripsi Bidang Ilmu Agama Islam. Jakarta: Raja Grafindo Persada.

Didi Kusnadi. 2011. Bantuan Hukum Dalam Hukum Islam Profesi Kepengacaraan Dalam Islam Dan Praktiknya Di Lingkungan Peradilan Agama. Bandung : Sahifa.

Hadi Abdul. 2015. Fiqh Munakahat. Semarang : Karya Abadi Jaya.

IAIN Sunan Ampel Surabaya. 2008. Modul Pelatihan Kuliah Kerja Nyata (KKN) Transformatif IAIN Sunan Ampel Surabaya. Surabaya: LPM IAIN Sunan Ampel.

Laurence Steinberg. 2001. Adolescence dalam. The Gale Encyclopedia of Psychology, ed. Bonnie Strictland, Farmingon Hills: Gale Group.

Lexy J Maleong. 1989. Metode Penelitian Kualitatif. Bandung: Rosda Karya.

Moh. Nazir. 2005. Metode Penelitian. Cet. 6. Bogor: Ghalia Indonesia.

Mustafa Kamal. 2003. Fikih Sunnah. Yogyakarta: Citra Karsa Mandiri.

Oyo Sunaryo Mukhlas. 2011. Perkembangan Peradilan Islam. Cet. I. Bogor: Ghalia Indonesia.

Sabiq Sayyid. 2009. Fiqh Sunnah 4, Terjemah: Abdur Rahim dan Masruhin. Jakarta: Cakrawala Publising.

Salim HS dan Erlies Septiana Nurbani. 2016. Penerapan Teori Hukum pada Penelitian Tesis dan Desertasi. Ed. 1. Cet. 4. Jakarta : Rajawali Pres.

Soerjono Soekanto. 2016. Faktor-Faktor Yang Mempengaruhi Penegakan Hukum. Cet. 14. Jakarta : Raja Grafindo Persada.

Slamet Abidin. 1999. Fiqih Munakahat Cet. I. Bandung: CV Pustaka Setia.

Syaikh Hasan Ayyub. 2006. Fikih Keluarga cet. I. Jakarta: Pustaka al-Kausar.

Sayyid Sabiq. 2009. Fiqih Sunnah Cet. I, jilid 3. Jakarta: P.T. Pena Pundi Aksara.

Tutuk Hamidah. 2011. Fiqh Perempuan Berwawasan Keadilan Gender. Malang: UIN Maliki Press. HIm. 127.

Tim Redaksi Nuansa Aulia. 2012. Kompilasi Hukum Islam, (cet 4). Bandung: Nuansa Aulia.

Universitas Islam Negeri Sunan Gunung Djati Bandung. 2010. Pedoman Penyusunan Karya Tulis Ilmiah Skripsi, Tesis dan Disertasi. 
Aziz Sholeh, Dian Rachmat Gumelar, Aah Tsamrotul Fuaah - Pendampingan Hak-Hak Perempuan....

Wahyu Widiana (Direktur Jendral Badan Peradilan Agama MA RI). 2010. Pembinaan Peradilan Agama Dan Upaya Peningkatan Akses Terhadap Keadilan Untuk Semua (Justice For All). Makalah. Disampaikan di Rakernas MA RI. Balikpapan Kalimantan Timur. 